\title{
The Post-Wildfire Impact of Burn Severity and Age on Black Carbon Snow Deposition and Implications for Snow Water Resources, Cascade Range, Washington
}

\author{
TED M. UECKER AND SUSAN D. KASPARI \\ Department of Geological Sciences, Central Washington University, Ellensburg, Washington \\ KeITH N. Musselman \\ Institute of Arctic and Alpine Research, University of Colorado Boulder, Boulder, Colorado \\ S. MCKENZIE SKILES \\ Department of Geography, University of Utah, Salt Lake City, Utah
}

(Manuscript received 13 January 2020, in final form 2 May 2020)

\begin{abstract}
Wildfires in the snow zone affect ablation by removing forest canopy, which enhances surface solar irradiance, and depositing light absorbing particles [LAPs, such as black carbon (BC)] on the snowpack, reducing snow albedo. How variations in $\mathrm{BC}$ deposition affects post-wildfire snowmelt timing is poorly known and highly relevant to water resources. We present a field-based analysis of BC variability across five sites of varying burn age and burn severity in the Cascade Range, Washington State, United States. Single particle soot photometer (SP2) analyses of BC snow concentrations were used to assess the impact of BC on snow albedo, and radiative transfer modeling was used to estimate the radiative effect of BC on snowmelt. Results were compared to Snowpack Telemetry (SNOTEL) data from one site that burned in 2012 and another in a proximal unburned forest. We show that post-wildfire forests provide a significant source of BC to the snowpack, and this effect increases by an order of magnitude in regions of high versus low burn severity, and decreased by two orders of magnitude over a decade. There is a shift in the timing of snowmelt, with snow disappearance occurring on average $19 \pm 9$ days earlier post-wildfire (2013-19) relative to pre-wildfire (19832012). This study improves understanding of the connection between wildfire activity and snowmelt, which is of high relevance as climate change models project further decreases in snowpack and increases in wildfire activity in the Washington Cascades.
\end{abstract}

\section{Introduction}

The snowpack plays an important role in the Earth system by modulating climate and providing a seasonal reservoir of water resources. In mountainous regions of the western United States, snowmelt accounts for more than $70 \%$ of the annual streamflow (Barnett et al. 2005; Li et al. 2017). In the Cascade Range of Washington State, $>50 \%$ of the annual precipitation accumulates as snow during the winter and spring, with subsequent melt runoff augmenting the dry summer (Mote 2006; Elsner et al. 2010; Vano et al. 2010). The availability of water resources is thus strongly related to the persistence of seasonal snowpack. In the western United States, spring snowpack is in widespread decline (Mote et al. 2018).

Corresponding author: Susan Kaspari, kaspari@geology.cwu.edu
This impact has been most pronounced in regions where winter temperatures are close to the freezing point, such as the U.S. Pacific Northwest and the Cascades. Here, slight warming can shift snowfall to rain and increase ablation rates, compromising the reliability of snow water resources (Nolin and Daly 2006).

In addition to warming temperatures, changes in snow surface albedo impact melt rates and timing. Snow has the highest albedo of any naturally occurring surface on Earth, with fresh snow able to reflect $80 \%-90 \%$ of solar radiation (Warren and Wiscombe 1980). Deposition on the snow surface of light-absorbing particles (LAPs) such as black carbon (BC; commonly referred to as soot), organic carbon (OC), and dust darken the surface, reduce albedo, and increase the solar radiation absorbed by the snowpack (Hansen and Nazarenko 2004; Andreae and Gelencsér 2006; Painter et al. 2012). 
Slight reductions in snow albedo can increase melt rates and alter the timing and magnitude of seasonal streamflow (Hall 2004; Flanner et al. 2009; Skiles et al. 2012).

Warming temperatures and less persistent snow cover have led to increases in wildfire frequency, magnitude, severity, and duration in the western United States (Westerling et al. 2006; Littell et al. 2010; Flannigan et al. 2013). Fire suppression activities in the Cascade Range and elsewhere have altered the presettlement fire regime, resulting in increased forest density and altered species composition, especially in lower-elevation forests (Arno 1980; Smith and Fischer 1997; Wright and Agee 2004). This has led to high burn severity wildfires on the eastern slope of the Cascade Range since the 1980s that have created large areas of burned forest exceeding historical conditions of snag production, occurrence, and decay (Everett et al. 1999). From 2000 to $2012,80 \%$ of all wildfires in the western United States occurred in the seasonal snow zone, burning $44000 \mathrm{~km}^{2}$ (Gleason et al. 2013). The summer fire season is projected to extend by 20 days by the middle of this century, while the area burned by fire regionally is projected to increase by $100 \%-250 \%$ (Littell et al. 2010; Flannigan et al. 2013).

Wildfires in the seasonal snow zone decrease forest canopy cover, which increases shortwave solar radiation that reaches the snow surface, and deposit LAP which reduces surface albedo (Burles and Boon 2011; Winkler 2011; Harpold et al. 2014). Previous studies have demonstrated that post-wildfire deposition of burned woody debris on the snow advanced the timing of snowmelt by 23 days compared to an unburned forest the first winter following a wildfire, and burned woody debris accelerated snow depletion for three subsequent years post-wildfire in the Oregon Cascades (Gleason et al. 2013; Gleason and Nolin 2016). Using satellite imagery Gleason et al. (2019) observed that snow disappeared on average 5 days earlier in approximately 850 burned forests compared to nearby unburned forests across the western United States, and this trend persisted for $>10$ years after fire. Furthermore, Gleason et al. (2019) used surficial snow samples to demonstrate that post-wildfire deposition of BC on snow increased the radiative forcing on snow for up to 15 years following fire occurrence. In the Pacific Northwest, high concentrations of $\mathrm{BC}$ are not limited to the snowpack in recently burned forests, but have also been reported on glacier surfaces during the forest fire season (Delaney et al. 2015; Kaspari et al. 2015). Thus, the impacts of BC deposition on regional snow water resources can be far reaching and can persist for many years post-wildfire.

Despite important advances from recent studies, more work is needed to better constrain how $\mathrm{BC}$ from charred trees contributes to snow albedo reductions and how this effect varies with burn age and burn severity. These dynamics are not currently considered in operational snowmelt forecasting, or in Earth system models (e.g., Li et al. 2013). Resolving the effects of wildfire on snowpack is of critical importance in the western United States and particularly in the Cascade Range, where snow water resources are at exceptional risk of climate change and severe wildfire (Nolin and Daly 2006; Allen et al. 2010). Here, we present field- and laboratorybased experiments of snow surface BC to assess how BC deposition in post-wildfire forests varies temporally, spatially, and with burn severity. These data are then used to model the contribution of post-wildfire deposition of BC to altered snowmelt rates in the Cascade Mountains of Washington State, and compared to Snowpack Telemetry (SNOTEL) data from a burned and unburned SNOTEL station in the study area.

\section{Methods}

\section{a. Site description}

Fieldwork was conducted at five locations in the Okanogan-Wenatchee and Mt. Baker-Snoqualmie National Forests in Washington State, United States (Fig. 1). BC concentrations in the snowpack are highest after the date of maximum snow water equivalent (SWE), when seasonal snow accumulation has ceased and BC loss due to melt is minimal (Delaney et al. 2015). Because of this, snow samples and photographs (section 2b) were collected after peak SWE as measured by regional SNOTEL sensors (http://www.wcc.nrcs.usda.gov/snow) to measure the maximum $\mathrm{BC}$ deposited in a given location over the entire snow accumulation season. For all sites used in this study, sampling areas were identified using data provided by the Monitoring Trends in Burn Severity project (MTBS.gov), which uses Landsat imagery collected since 1984 to map the extent of each burn area, and divides burn severity into four categories (unburned, low, moderate, and high) based on the alteration of vegetation and landscape. These maps have a resolution of $30 \mathrm{~m}$ and are used to study the post-wildfire effects on landscapes as well as assess hazards including erosion and increased runoff (Eidenshink et al. 2007). These maps were used to identify large, contiguous areas of homogenous burn severity which were fairly recognizable in the field by snag condition, and all sampling locations were recorded using a handheld GPS and referenced against the MTBS data using ArcMap geographic information system (GIS) software (https://desktop.arcgis.com/en/arcmap/).

The primary study area (Table Mountain; Fig. 1) was sampled on seven days total in March-April 2015 and 

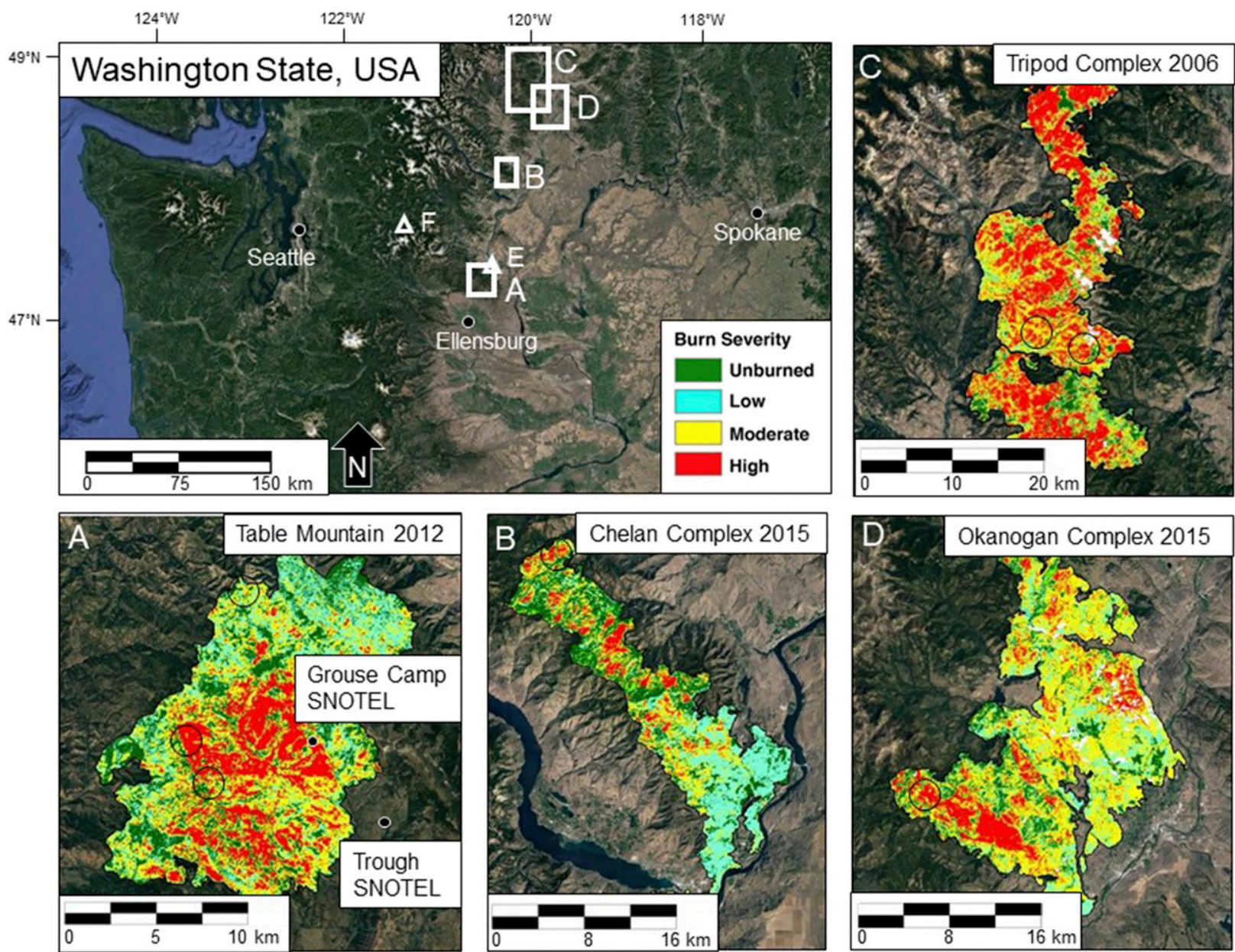

FIG. 1. Map of Washington State including the four study sites (A, B, C, and D) and two control sites: Tronsen Meadow (E) and Stevens Pass (F). Insets include burn severity maps with sample locations included in black circles (modified from MTBS.gov). SNOTEL sites are shown as triangles on the state map, and labeled for inset $\mathrm{A}$.

April-May 2016. The Table Mountain fire (ignited on 8 September 2012) was sampled in mixed burn severity areas, with mixed forest density and mostly standing snags. This area contains the Grouse Camp SNOTEL station $\left(47.2808^{\circ} \mathrm{N}, 120.4878^{\circ} \mathrm{W}, 1643 \mathrm{~m}\right)$, which was completely burned in the 2012 fire (Fig. 2), and promptly rebuilt in the exact same location with the same type of snow pillow (S. Pattee 2016, NRCS, personal communication), allowing comparison of SWE from pre- and post-wildfire years. We also use data from the Trough
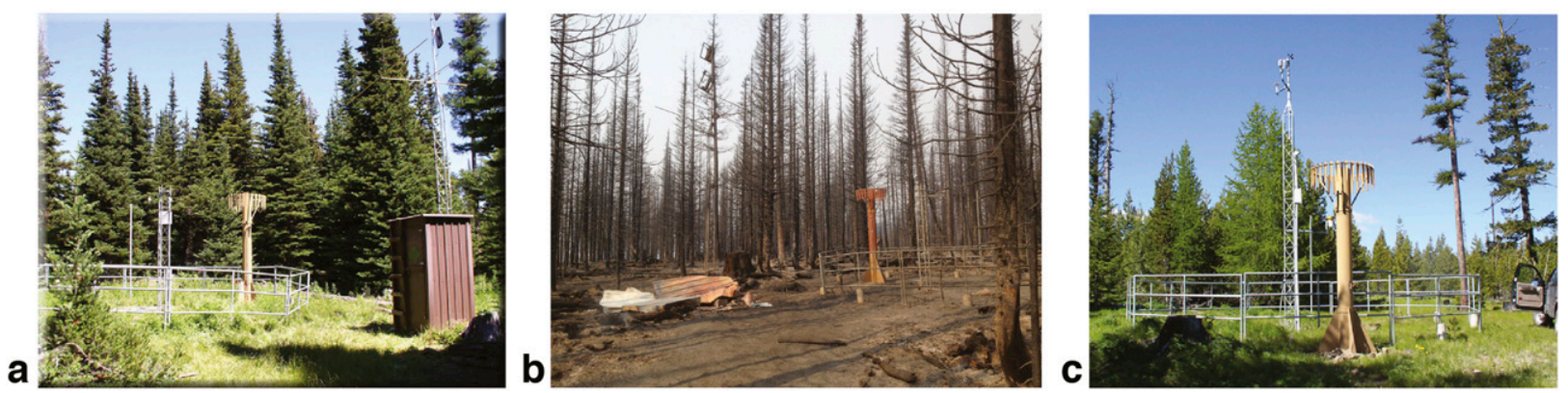

FIG. 2. (a) Pre- and (b) post-wildfire conditions in 2012 at the Grouse Camp SNOTEL site, which was classified as high burn severity (photographs courtesy of Scott Pattee), and (c) the unburned Trough SNOTEL site (NRCS). 
SNOTEL station $\left(47.233251^{\circ} \mathrm{N}, 120.4294157^{\circ} \mathrm{W}, 1670 \mathrm{~m}\right)$ located in an unburned area $15 \mathrm{~km}$ downwind of the Table Mountain burn (Fig. 1).

Additional study sites of varying burn age were identified in the Washington Cascades. For comparison to an older burn area, the Tripod Complex (ignited on 24 July 2006) was sampled in moderate to high burn severity areas with high forest density and substantial snag fall. The most recent fires in this study both ignited on 14 August 2015. The Black Canyon fire (part of the Chelan Complex) was sampled in a moderate burn severity area with low forest density. The Lime Belt fire (part of the Okanogan Complex) was sampled in a high burn severity area with high forest density and all standing snags. Control samples were collected at the lightly burned Tronsen Meadow and unburned Stevens Pass in March and April of 2016. The former site is adjacent to Table Mountain and has prior BC concentration data from 2012 to 2013 (Delaney et al. 2015), which was used in conjunction with data collected during this study. The latter site is far removed and upwind of any recent regional wildfires. All sites used in this study are in a similar elevation range, are pine and fir dominated, and the prevailing wind direction is west-northwest (https://wrcc.dri.edu). Sample locations within each study area were selected to capture the full range of snow conditions, from fresh snow with no surrounding snags to visibly darkened snow in severely burned areas. Care was taken to sample in flat, contiguous areas of anthropogenically undisturbed forest far removed from access roads. Site data and forest characterization are included in Table 1.

\section{b. Field methods}

Data collection in the field consisted of snow sample collection and measurements of snow depth, density, and SWE. Albedo is most strongly affected by BC content at the snow surface, or in the top few centimeters (Skiles and Painter 2017), and BC generally accumulates at the surface during the melt process, further accelerating melt in a positive feedback (e.g., Doherty et al. 2014). Thus, snow samples for BC analysis were collected from the surface (upper $2 \mathrm{~cm}$ ) at each site using a clean polypropylene $14 \mathrm{~cm} \times 25 \mathrm{~cm}$ rectangle into sealable Whirlpak polyethylene bags, and directly into $50-\mathrm{mL}$ polypropylene vials. Cores of the snowpack at each site were collected to measure total BC deposited in the snowpack. Cores were collected with a SnowHydro $160-\mathrm{cm}$ coring tube with a $6.2-\mathrm{cm}$ diameter, removed from the coring tube using a custom-made PVC plunger with care taken to minimize sample compression, and then divided into approximately 80-cm segments and collected into polyethylene bags. The snowpack density was calculated using the coring tube dimensions, core sample mass, and the height of the snowpack.

To measure how BC deposition on the snowpack changes with burn severity, snow surface samples were compared for 1) all post-wildfire study sites and 2) only the Table Mountain site to control for variations in BC deposition with burn age. These data were compared to samples collected at Tronsen Meadow and Stevens Pass in unburned areas adjacent to and far removed from wildfire areas, respectively (Fig. 1). To measure the difference in $\mathrm{BC}$ deposition as burned trees age and decay, snow samples were collected in forests of varying burn age. Sample ages (denoted as year since fire) were calculated as the difference in the collection date of the sample and the ignition date of the corresponding fire, and range from 0.7 years for the Okanogan and Chelan Complexes to 2.65 and 3.75 years for Table Mountain and 9.8 years for the Tripod Complex.

\section{c. Laboratory methods}

\section{1) SAMPLE PREPARATION}

All snow samples were kept frozen at $-18.0^{\circ} \mathrm{C}$ until just prior to analysis. Vial samples were melted directly by partial submersion in a warm water bath, while Whirlpak and core samples were transferred to clean, preweighed 500-mL Pyrex jars before melting. Following complete melt, all samples were sonicated for $15 \mathrm{~min}$ prior to analysis in a Branson 5510 sonicator filled with ultrapure deionized water. All samples were analyzed by the single particle soot photometer (SP2) shortly after melting to minimize losses in measured BC concentrations when stored in the liquid phase (Menking 2013; Wendl et al. 2014).

\section{2) Single PARTicle SoOT PHOtometer ANALYSIS}

The SP2 (Droplet Measurement Technologies, Boulder, Colorado) measures the number and size of BC particles using neodymium-yttrium aluminum garnet (Nd-YAG) laser-induced incandescence. Photometers detect the thermal radiation produced by individual $\mathrm{BC}$ particles. This method is advantageous due to the use of small sample volumes $(\sim 5 \mathrm{~mL})$ and minimal interference from other LAPs in the sample (e.g., Gao et al. 2007; Kaspari et al. 2011; Schwarz et al. 2012; Torres et al. 2014; Wendl et al. 2014; Mori et al. 2016).

$\mathrm{BC}$ calibration standards ranging from 0.5 to $30 \mu \mathrm{g} \mathrm{L}^{-1}$ were prepared daily using Aquadag (Acheson Industries, United States), a graphite-based lubricant. Calibration curves were created to correct measured $\mathrm{BC}$ concentrations, 
TABLE 1. Sample site information and forest characterization (from inciweb.nwgc.gov). The letters under "site" correspond to the locations shown in Fig. 1.

\begin{tabular}{|c|c|c|c|c|c|c|}
\hline Site & Location & $\begin{array}{l}\text { Elevation } \\
\quad(\mathrm{m})\end{array}$ & Date burned & Date(s) sampled & $\begin{array}{l}\text { Area burned: } \\
\text { high severity } \\
\quad\left(\mathrm{km}^{2}\right)\end{array}$ & Forest characterization \\
\hline $\begin{array}{l}\text { A. Table } \\
\text { Mountain }\end{array}$ & $47.2435^{\circ} \mathrm{N} 120.5595^{\circ} \mathrm{W}$ & 1920 & 8 Sep 2012 & $\begin{array}{c}19 \text { Mar } 2015,15 \text { Apr } \\
2015,23 \text { Apr } 2015, \\
29 \text { Apr } 2015,02 \text { Apr } \\
\text { 2016, } 12 \text { Apr } 2016, \\
11 \text { May } 2016\end{array}$ & 267:56 & $\begin{array}{l}\text { Douglas fir, lodgepole pine, } \\
\text { western larch, subalpine } \\
\text { fir, grand fir, } \\
\text { ponderosa pine }\end{array}$ \\
\hline $\begin{array}{l}\text { B. Chelan } \\
\text { Complex }\end{array}$ & $48.0510^{\circ} \mathrm{N} 120.1120^{\circ} \mathrm{W}$ & 915 & 14 Aug 2015 & 18 Apr 2016 & $132: 20$ & Douglas fir, ponderosa pine \\
\hline $\begin{array}{l}\text { C. Tripod } \\
\text { Complex }\end{array}$ & $48.6192^{\circ} \mathrm{N} 120.1076^{\circ} \mathrm{W}$ & 1830 & 24 Jul 2006 & $\begin{array}{l}17 \text { Apr } 2016, \\
24 \text { Apr } 2016\end{array}$ & $242: 86$ & $\begin{array}{l}\text { Douglas fir, lodgepole pine, } \\
\text { subalpine fir, some } \\
\text { ponderosa pine }\end{array}$ \\
\hline $\begin{array}{l}\text { D. Okanogan } \\
\text { Complex }\end{array}$ & $48.4360^{\circ} \mathrm{N} 119.8520^{\circ} \mathrm{W}$ & 1859 & 14 Aug 2015 & 23 Apr 2016 & $540: 81$ & Douglas fir, ponderosa pine \\
\hline E. Stevens Pass & $47.7567^{\circ} \mathrm{N} 121.0970^{\circ} \mathrm{W}$ & 1554 & - & 27 Apr 2016 & - & $\begin{array}{l}\text { Douglas fir, lodgepole pine, } \\
\text { ponderosa pine, western } \\
\text { white pine, western } \\
\text { hemlock }\end{array}$ \\
\hline $\begin{array}{r}\text { F. Tronsen } \\
\text { Meadow }\end{array}$ & $47.2658^{\circ} \mathrm{N} 120.5743^{\circ} \mathrm{W}$ & 1676 & $\begin{array}{c}\text { - (adjacent } \\
\text { to Table } \\
\text { Mountain })\end{array}$ & 19 Mar 2016 & - & $\begin{array}{l}\text { Douglas fir, lodgepole pine, } \\
\text { subalpine fir, grand fir, } \\
\text { ponderosa pine }\end{array}$ \\
\hline
\end{tabular}

and all analyses were blank-corrected based on ultrapure deionized water blanks $\left(\sim 18 \mathrm{M} \Omega \mathrm{cm}^{-1}, 25.0^{\circ} \mathrm{C}\right)$. Samples with a highly visible particle load (or samples with measured incandescent particle concentrations above the highest calibrated value) underwent serial dilutions, and three samples were measured from each snow sample, both to check the precision of the dilution and to assess the heterogeneity of the sample.

Samples were analyzed while being magnetically stirred for increased homogeneity. The setup used for these measurements includes an Ismatec peristaltic pump (Cole-Parmer, Wertheim, Germany) set to $0.14 \mathrm{~mL} \mathrm{~min}^{-1}$ and calibrated every 15-20 samples, that delivers liquid sample to a Cetac Marin-5 nebulizer set to $110^{\circ} \mathrm{C}$ heating, $5^{\circ} \mathrm{C}$ cooling following Mori et al. (2016). The Marin-5 receives standard laboratory air at $1000 \mathrm{sccm}$ (standard cubic centimeters per minute; $1.000 \mathrm{~L} \mathrm{~min}^{-1}$ ) that is regulated by a flow monitor (Alicat Scientific, Inc., Tucson, Arizona) connected to a Drierite Gas Purifier, which removes any moisture or particulates from the air. Raw data were collected using Droplet Measurement Technologies' SP2 Acquisition Software Version 4.1. Between 5000 and 50000 particles were recorded to a data file for each sample depending on the sample incandescent concentration (number of particles per $\mathrm{cm}^{3}$ of sample). BC concentrations were determined using the
SP2 toolkit 4000 (Paul Scherrer Institute, Villigen, Switzerland).

\section{d. Radiative transfer modeling for albedo and radiative forcing}

Snow albedo measurements were not made coincident with snow sampling for BC content. Therefore, spectral snow albedo was modeled with the Snow, Ice, and Aerosol Radiation model (SNICAR; Flanner et al. 2007), which computes multiple scattering and reflectance from snow and LAP mixtures across 470 bands $(0.3-5.0 \mu \mathrm{m})$ at $10-\mathrm{nm}$ resolution. LAP mixing ratios can be specified for multiple particle types, including BC and dust, though for this study the only LAP input was the $\mathrm{BC}$ concentrations measured using the SP2 (see section 2c). Snow property inputs include snow effective grain size, snow density, snow depth, and concentrations of LAP. Other inputs include the solar zenith angle, type of atmosphere for irradiance distribution, and ground/substrate albedo.

Our objective was to characterize the magnitude of snow albedo decline and the radiative forcing-the enhanced surface absorption of shortwave radiation due to the presence of LAP - that corresponds to sampled BC concentrations to constrain the potential contribution to enhanced melt from $\mathrm{BC}$ radiative forcing. We modeled albedo for a range of sampled $\mathrm{BC}$ concentrations for two 
different grain sizes representing medium to well-aged seasonal snow (300 and $700 \mu \mathrm{m}$ ) under clear and cloudy sky conditions. We assume a snow density of $400 \mathrm{~kg} \mathrm{~m}^{-3}$ consistent with measured values of uncompressed snowpack depth and from snow core samples collected in the field. RF requires an estimate of clean snow albedo. For each BC scenario, we modeled albedo with and without $\mathrm{BC}$ for the same grain size and then calculated the difference in absorption, which quantifies the direct radiative impact due to snow darkening.

The broadband albedo and radiative forcing $\left(\mathrm{W} \mathrm{m}^{-2}\right)$ was calculated in combination with the spectral distribution of incoming solar radiation, which was modeled over daylight hours of the pre- and post-wildfire ablation seasons for both clear and cloudy sky conditions between 0.35 and $2.5 \mu \mathrm{m}$ at $10-\mathrm{nm}$ resolution with the Santa Barbara DISORT Atmospheric Radiative Transfer model (SBDART) (Ricchiazzi et al. 1998). The pre- and post-wildfire ablation seasons were determined from long-term data at the Grouse Camp SNOTEL station (section 2e). Using albedo from SNICAR and irradiance from SBDART irradiance, spectrally weighted albedo between 0.35 and $2.5 \mu \mathrm{m}$ was calculated by dividing the product of the summation of irradiance and albedo by the summation of irradiance:

$$
\alpha=\frac{\sum_{\lambda=0.35 \mu \mathrm{m}}^{2.5 \mu \mathrm{m}} I \alpha_{\mathrm{lap}} \Delta \lambda}{\sum_{\lambda=0.35 \mu \mathrm{m}}^{2.5 \mu \mathrm{m}} I \Delta \lambda},
$$

where $I$ is spectral irradiance at the given solar zenith angle, $\alpha_{\text {lap }}$ is the modeled albedo with BC at the same solar zenith angle, and $\lambda$ is the wavelength $(\mu \mathrm{m})$. Radiative forcing was calculated by taking the summation of the product of spectral irradiance and the difference between the spectrally weighted $\mathrm{BC}$ albedo and clean snow albedo, which represents the enhanced surface absorption due to $\mathrm{BC}$ :

$$
\mathrm{RF}=\sum_{\lambda=0.35 \mu \mathrm{m}}^{2.5 \mu \mathrm{m}} I(\Delta \alpha) \Delta \lambda,
$$

where $\Delta \alpha=\alpha_{\text {clean }}-\alpha_{\text {lap }}$, which is the difference between clean and BC laden snow albedo at the same hour, for the same snow grain size and density. We report daily maximum and daily mean all sky radiative forcing values, which are the average between clear and cloudy sky conditions.

\section{e. Analysis of wildfire impacts on snowmelt dynamics}

To investigate the impact of the 2012 Table Mountain fire on the rate and timing of snowmelt, SWE data from the Grouse Camp SNOTEL station that was severely burned and promptly rebuilt was compared to SWE data from the nearby $(15 \mathrm{~km}$ downwind) unburned Trough SNOTEL station (Figs. 1 and 2). The close proximity (approximately $15 \mathrm{~km}$ ) and similar elevations (Grouse Camp: 1643 m, Trough: $1670 \mathrm{~m}$ ) of the two stations allowed for a unique controlled assessment of the changes in snowmelt timing and rates in a burned versus unburned forest. We compare snowpack metrics including peak SWE, the first snow disappearance date (FSSD) occurrence after 1 January (Trujillo and Molotch 2014), the average daily melt rate $\geq 2.54 \mathrm{~mm}$ (the measurement precision of a SNOTEL SWE sensor) occurring after 1 January, and cumulative daily melt $\geq 2.54 \mathrm{~mm}$ after 1 January for pre-wildfire $(1982-2012 ; n=30)$ and post-wildfire $(2013-19 ; n=7)$ years at the burned Grouse Camp SNOTEL to that measured at the unburned Trough SNOTEL site. In addition, a normalized melt frequency metric was computed as the number of days after 1 January with measurable melt $(\geq 2.54 \mathrm{~mm})$ divided by the number of days after 1 January with measurable SWE $(\geq 2.54 \mathrm{~mm})$. For both SNOTEL sites, this annual metric was averaged for pre- and post-wildfire periods. Statistically significant at the $5 \%$ level of pre- and post-wildfire snowpack metrics at both sites were assessed using a two-sample Kolmogorov-Smirnov test.

To isolate the enhanced melt due to BC from wildfires, we present a simple energy contribution analysis using output from the radiative transfer modeling (section $2 \mathrm{~d}$ ). The additional melt due to the presence of $\mathrm{BC}$ in snow was estimated by dividing the all-sky shortwave radiative forcing by the enthalpy of fusion of water at $0^{\circ} \mathrm{C}\left(0.334 \times 10^{6} \mathrm{~J} \mathrm{~kg}^{-1}\right)$ to estimate melt in kilograms per square meter (note, $1 \mathrm{~kg} \mathrm{~m}^{-2}$ of water is equivalent to $1 \mathrm{~mm}$ ). This was conducted for two distinct time periods: pre- and post-wildfire snowmelt periods defined as the dates over which $25 \%-75 \%$ of the cumulative melt (measured at Grouse Camp) occurred before (1983-2012) and after (201218) the Table Mountain Fire. This assessment required the assumption that the snow cold content is depleted (i.e., snow temperature is $0^{\circ} \mathrm{C}$ ), which is a reasonable assumption for spring snow-cover. We also calculated the additional melt due to post-wildfire BC deposition, and assume that the hypothetical site is in the open and unaffected pre- and post-wildfire by forest shading.

\section{Results}

\section{a. Variations in $B C$ deposition with burn age}

The amount of BC deposited on the snowpack in the years following a wildfire decays following a power law 
(Figs. 3a,b). The photos in Fig. 3 show examples of the observed differences in the amount of charred material on the snow and remaining on the trees in the first year (the Okanogan Complex site; Fig. 3e) and 9.8 years (the Tripod Complex site; Fig. 3f) after a fire. Samples of differing burn age were compared separately for all burn severities and high burn severity (Fig. 3) to isolate the effects of burn severity on $\mathrm{BC}$ deposition (discussed below).

$\mathrm{BC}$ concentrations in all burn severities (Fig. 3a) are an order of magnitude higher in the first winter postwildfire $\left(n=20\right.$; mean $=1671.1 \mathrm{ngg}^{-1}$; median $=$ $1131.1 \mathrm{ngg}^{-1} ; \sigma=1537.5 \mathrm{ng} \mathrm{g}^{-1} ; \max =4930.3 \mathrm{ng} \mathrm{g}^{-1}$ ) relative to 9.8 years post-wildfire $(n=20$; mean $=$ $87.5 \mathrm{ngg}^{-1} ;$ median $=67.5 \mathrm{ng} \mathrm{g}^{-1} ; \sigma=86.7 \mathrm{ngg}^{-1}$; $\left.\max =282.5 \mathrm{ng} \mathrm{g}^{-1}\right)$. Median BC concentration values $\left(67.5 \mathrm{ng} \mathrm{g}^{-1}\right)$ in the Tripod Complex remained above background (unburned; $10 \mathrm{ng} \mathrm{g}^{-1}$ ) after 9.8 years.

Likewise, $\mathrm{BC}$ concentrations in high burn severity (Fig. 3b) are also an order of magnitude higher in the first winter post-wildfire $\left(n=16\right.$; mean $=2024.9 \mathrm{ng} \mathrm{g}^{-1}$; median $=1131.1 \mathrm{ngg}^{-1} ; \sigma=1525.3 \mathrm{ngg}^{-1} ; \max =$ $\left.4930.3 \mathrm{ng} \mathrm{g}^{-1}\right)$ relative to 9.8 years post-wildfire $(n=10$; mean $=106.0 \mathrm{ng} \mathrm{g}^{-1} ;$ median $=70.9 \mathrm{ng} \mathrm{g}^{-1} ; \sigma=$ $102.7 \mathrm{ng} \mathrm{g}^{-1}$; $\max =282.5 \mathrm{ng} \mathrm{g}^{-1}$ ). Median BC concentration values $\left(70.9 \mathrm{ng} \mathrm{g}^{-1}\right)$ in a high burn severity area in the Tripod Complex remained above background (unburned; $10 \mathrm{ng} \mathrm{g}^{-1}$ ) after 9.8 years post-wildfire.

Snow core BC data collected from all sites also indicate that $\mathrm{BC}$ concentrations decrease with increasing burn age, consistent with the surface snow $\mathrm{BC}$ data. The snow core BC data are presented as total BC [Eq. (3)], which represents $\mathrm{BC}$ deposition during the entire snow season independent of snow accumulation, as opposed to $\mathrm{BC}$ concentrations derived from surface samples which influence albedo and are affected by snow accumulation and melt:

$$
\mathrm{BC}_{\text {total }}=\mathrm{BC}_{\mathrm{avg}} \times \rho \times D,
$$

where $\mathrm{BC}_{\text {total }}$ is the total deposited $\mathrm{BC}\left(\mathrm{ng} \mathrm{cm}^{-2}\right), \mathrm{BC}_{\mathrm{avg}}$ is the $\mathrm{BC}$ concentration $\left(\mathrm{ng} \mathrm{g}^{-1}\right), \rho$ is the measured snow density $\left(\mathrm{g} \mathrm{cm}^{-3}\right)$, and $D$ is the measured snowpack depth (cm) (Delaney et al. 2015). The snow core data have high variability, but suggest an order of magnitude decrease in median BC deposition from 0.7 years post-wildfire $(n=8$; mean $=3928.9 \mathrm{ng} \mathrm{cm}^{-2} ;$ median $=3139.2 \mathrm{ng} \mathrm{cm}^{-2} ; \sigma=$ $2927.9 \mathrm{ng} \mathrm{cm}^{-2} ; \max =11377.6 \mathrm{ng} \mathrm{cm}^{-2}$ ) to 9.8 years post-wildfire $\left(n=5\right.$; mean $=919.0 \mathrm{ng} \mathrm{cm}^{-2}$; median $=$ $596.8 \mathrm{ng} \mathrm{cm}^{-2} ; \sigma=631.2 \mathrm{ng} \mathrm{cm}^{-2} ; \max =2059.7 \mathrm{ng} \mathrm{cm}^{-2}$ ).

\section{b. Variations in BC deposition with burn severity}

Surficial BC concentrations increased with burn severity by up to two orders of magnitude throughout all study locations (Fig. 3c). BC concentrations in unburned areas $\left(n=13 ;\right.$ mean $=12.8 \mathrm{ng} \mathrm{g}^{-1} ;$ median $=11.0 \mathrm{ng} \mathrm{g}^{-1}$; $\left.\sigma=8.6 \mathrm{ngg}^{-1} ; \max =34.0 \mathrm{ng} \mathrm{g}^{-1}\right)$ were consistent with the findings of Delaney et al. (2015). BC concentrations were similar in low burn severity $(n=30$; mean $=$ $75.7 \mathrm{ngg}^{-1} ;$ median $=45.5 \mathrm{ngg}^{-1} ; \sigma=117.5 \mathrm{ng} \mathrm{g}^{-1}$; $\max =637.7 \mathrm{ng} \mathrm{g}^{-1}$ ) and moderate burn severity areas $\left(n=35 ;\right.$ mean $=136.6 \mathrm{ngg}^{-1} ;$ median $=93.7 \mathrm{ng} \mathrm{g}^{-1} ; \sigma=$ $127.4 \mathrm{ng} \mathrm{g}^{-1} ; \max =525.9 \mathrm{ng} \mathrm{g}^{-1}$ ), while the highest BC concentrations and range of values were observed in high burn severity areas $\left(n=104\right.$; mean $=666.0 \mathrm{ng} \mathrm{g}^{-1}$; median $=208.4 \mathrm{ngg}^{-1} ; \sigma=1010.7 \mathrm{ngg}^{-1} ; \max =$ $4930.3 \mathrm{ng} \mathrm{g}^{-1}$ ).

Surficial BC concentrations were compared to areas of differing burn severity at the Table Mountain site alone to control for the effects of burn age on BC deposition observed with burn age (section 3a). The BC concentrations at Table Mountain increased with burn severity by up to two orders of magnitude (Fig. 3d) from low to high magnitude. BC concentrations in low severity areas $\left(n=29 ;\right.$ mean $=78.1 \mathrm{ng} \mathrm{g}^{-1}$; median $=$ $46.9 \mathrm{ngg}^{-1} ; \sigma=118.8 \mathrm{ngg}^{-1} ; \max =637.7 \mathrm{ngg}^{-1}$ ) are similar to the data from all study locations, since most of the low severity sampling was done at Table Mountain. $\mathrm{BC}$ concentrations from moderate severity areas $(n=$ 21 ; mean $=146.1 \mathrm{ngg}^{-1} ;$ median $=123.4 \mathrm{ngg}^{-1} ; \sigma=$ $141.8 \mathrm{ngg}^{-1}$; $\max =525.9 \mathrm{ngg}^{-1}$ ) is slightly higher at Table Mountain than the other study locations. The high severity burn area at Table Mountain $(n=80$; mean $=$ $448.3 \mathrm{ng} \mathrm{g}^{-1} ;$ median $=135.0 \mathrm{ng} \mathrm{g}^{-1} ; \sigma=661.3 \mathrm{ngg}^{-1}$; $\max =3401.6 \mathrm{ng} \mathrm{g}^{-1}$ ) yielded lower mean and median $\mathrm{BC}$ concentration values when compared to the high burn severity data from all study locations.

Total BC deposition at all sites measured from snow core data (section 3a) support the trend observed in the surface sample data, with median BC deposition increasing by an order of magnitude from low burn severity $\left(n=5\right.$; mean $=497.3 \mathrm{ng} \mathrm{cm}^{-2}$; median $=$ $517.7 \mathrm{ng} \mathrm{cm}^{-2} ; \sigma=177.7 \mathrm{ng} \mathrm{cm}^{-2} ; \max =741.0 \mathrm{ng} \mathrm{cm}^{-2}$ ) to high burn severity $\left(n=26\right.$; mean $=1978.9 \mathrm{ng} \mathrm{cm}^{-2}$; median $=1146.4 \mathrm{ng} \mathrm{cm}^{-2} ; \sigma=2106.5 \mathrm{ng} \mathrm{cm}^{-2} ; \max =$ $11377.6 \mathrm{ng} \mathrm{cm}^{-2}$ ), with the maximum deposition observed increased two orders of magnitude in high versus low severity burns.

\section{c. Model results of BC impacts on snow albedo and radiative forcing}

To demonstrate the powerful impact of the range of sampled BC concentrations, Fig. 4 shows modeled spectral albedo for clean snow, and for snow containing BC concentrations of 10, 50, 100, 1000, and $5000 \mathrm{ng} \mathrm{g}^{-1}$ $\mathrm{BC}$ for two effective grain sizes representing medium and large grain seasonal snow. For the same scenarios, 

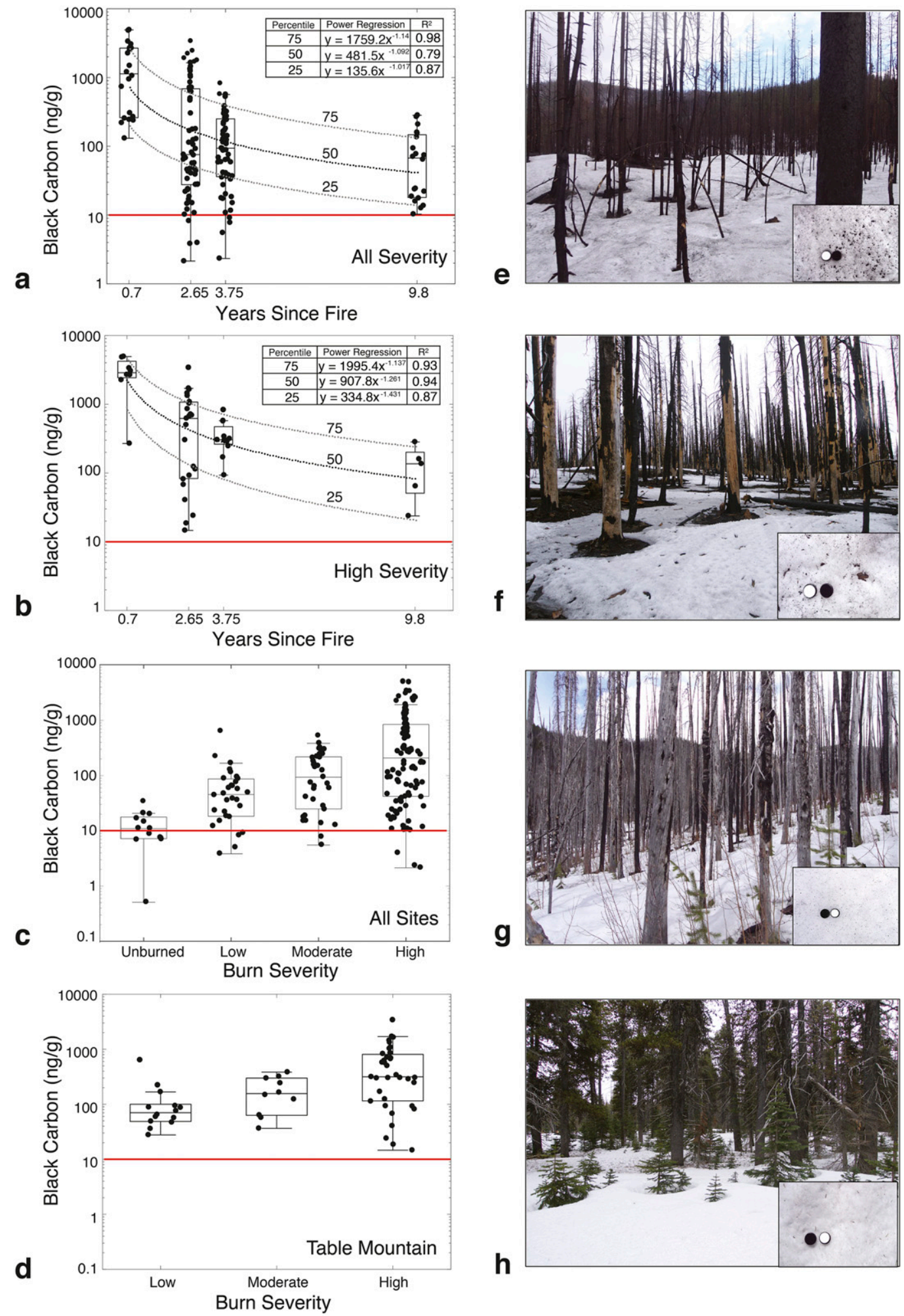

FIG. 3. (a) Surface BC concentrations in forests of variable burn age, including the 2006 Tripod Complex fire, 2012 Table Mountain fire (sampled in 2015 and 2016), and the 2015 Chelan and Okanogan Complex fires. The dotted lines represent power regressions for the 75th, 50th, and 25th percentiles, and the power regression equations and $R^{2}$ is displayed in the upper-right corner. (b) As in (a), but only for high burn severity areas. (c) Variations 
broadband albedo and daily mean and maximum (instantaneous value at solar noon) RF on 15 April and 15 May are summarized in Table 2. Even for snow in unburned areas $\mathrm{BC}$ concentrations of $10 \mathrm{ngg}^{-1}$ are nonnegligible, reducing albedo by $\sim 1 \%$, with daily maximum RF from 4 to $6 \mathrm{~W} \mathrm{~m}^{-2}$. For high severity burn areas sampled 0.7 years after a fire, with concentrations in the $3000-5000 \mathrm{ng} \mathrm{g}^{-1}$ range, snow albedo could reach as low as 0.37 , with daily mean $\mathrm{RF}$ as high as $185 \mathrm{~W} \mathrm{~m}^{-2}$, and maximum radiative forcing over $300 \mathrm{~W} \mathrm{~m}^{-2}$. For context, on a clear day in spring irradiance at solar noon is $\sim 900 \mathrm{~W} \mathrm{~m}^{-2}, 30 \%$ of which would be absorbed by BC in snow for the highest concentration presented here. Although the impact of post-wildfire BC deposition declines over time, our results show the impact could last for over a decade (Fig. 3). For BC concentrations sampled in high severity burn areas nearly a decade after fire occurrence $\left(\sim 100 \mathrm{ng} \mathrm{g}^{-1}\right)$ the mean daily potential $\mathrm{RF}$ is $15-20 \mathrm{~W} \mathrm{~m}^{-2}$.

\section{d. Snowpack response to wildfire as measured at a burned and unburned SNOTEL site}

\section{1) FIRST SNOW DISAPPEARANCE DATE}

Prior to the Table Mountain fire, the first snow disappearance date (FSDD) measured at the neighboring Grouse Camp and Trough SNOTEL sites (Fig. 5a) was significantly correlated (1983-2012; $n=30$ years, $r=$ $0.86, p<0.00001)$. The high correlation indicates that the two sites were affected by similar synoptic patterns and relative climate conditions. This is explained by the close proximity $(\sim 15 \mathrm{~km})$ and similar elevations $(\sim 1655 \mathrm{~m})$ of the two sites. However, the Grouse Camp station historically recorded nearly twice the peak SWE than the Trough station (1983-2012; Table 3), presumably due to the former being in a favorable location relative to the prevailing storm track and surrounding terrain. Before the wildfire (1983-2012), FSDD occurred on average $13 \pm 7$ days later at Grouse Camp than at the Trough site (Fig. 5a; note the solid line plotting above the dashed line). In the pre-wildfire record, Grouse Camp never became snow-free before
Trough. After the wildfire (2013-19), an opposite relationship was observed with FSDD occurring $6 \pm 6$ days earlier at the burned Grouse Camp site than at the unburned Trough site (Fig. 5a; note the solid line plotting below the dashed line). Figure $5 \mathrm{~b}$ shows a drastic postwildfire shift to earlier FSDD at Grouse Camp relative to Trough of $19 \pm 9$ days, on average. Our results suggest that LAP deposition has a dominant and persistent role in causing earlier snow disappearance after a wildfire-with the magnitude of the impact following a power law decrease over the course of a decade.

\section{2) Cumulative daily melt}

An assessment of the cumulative daily melt at the two SNOTEL sites shows that the timing of snowmelt changed dramatically post-wildfire at the burned site with 2.4 times more melt occurring before 1 April compared to pre-wildfire conditions (i.e., compare $31 \%-13 \%$; Figs. 5 c,d). A clear shift to earlier postwildfire melt at the burned site is inferred from the dashed line plotting above the solid line, particularly in March through May (Figs. 5c,d). In pre-wildfire years, only $56 \%$ of the total melt had occurred by 1 May with $44 \%$ remaining; post-wildfire, $84 \%$ had occurred with only $26 \%$ remaining. By comparison, pre- and post-wildfire cumulative melt patterns were similar at the unburned Trough site.

\section{3) Melt FRequenCy AND RAte}

Interestingly, the wildfire did not cause melt to occur more frequently or at higher rates at the burned Grouse Camp site compared to the unburned Trough site relative to the pre-wildfire historical conditions at both sites (Table 3). At the unburned Trough site, melt occurred $28 \%$ of the snow-covered days after 1 January, increasingly slightly to $33 \%$ in the post-wildfire period. A similar change was observed at the burned Grouse Camp site, with melt occurring on $30 \%$ of the snowcovered days after 1 January pre-wildfire and $32 \%$ postwildfire. Average melt rates at the burned and unburned sites were higher in the pre-wildfire period $(15.3 \pm 12.7$ and

\footnotetext{
in surface BC concentrations with burn severity in post-wildfire forests burned in 2006, 2012, and 2015. Unburned sites include Stevens Pass and Tronsen Meadow. (d) Variations in surface BC concentrations with burn severity at Table Mountain from samples collected in 2015 and 2016, following the 2012 Table Mountain fire. For (a)-(d), end caps show the 90th percentile and lower limit, boxes show the 75th, 50th, and 25 th percentiles. The red lines represent the average background level from the unburned control sites. (e) High burn severity forest in the Okanogan Complex 0.7 years since the fire. (f) High burn severity forest at Table Mountain 2.65 years since fire. (g) High burn severity forest in the Tripod Complex 9.8 years since the fire. (h) Low burn severity forest at Table Mountain. The inset photos in (e)-(h) show snowpack conditions at the respective sites. The white and black circles are Spectralon standards.
} 

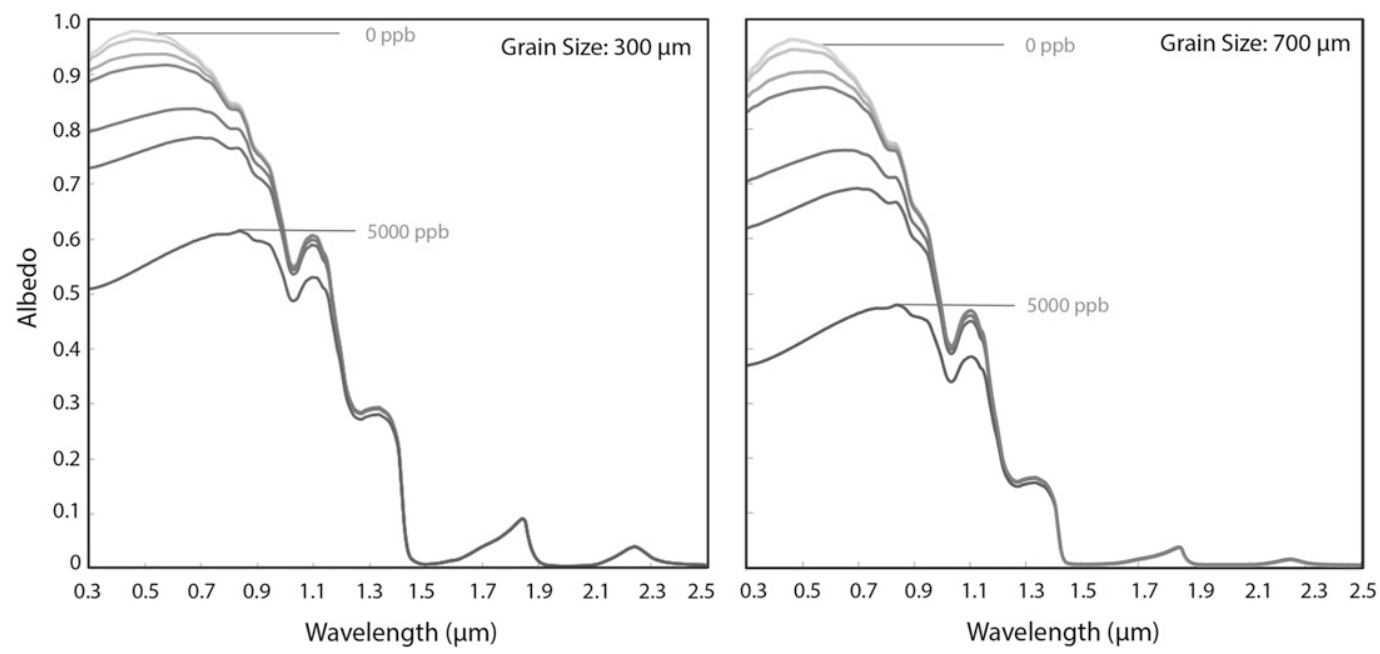

FIG. 4. Modeled decrease in spectral snow albedo approximately spanning the range of sampled BC concentrations $\left(10,50,100,500,1000,5000 \mathrm{ng} \mathrm{g}^{-1}\right)$ for two effective grain sizes. The uppermost spectral curve represents clean snow.

$11.5 \pm 8.7 \mathrm{~mm} \mathrm{day}^{-1}$, respectively) than in the years after the wildfire $\left(13.7 \pm 11.1\right.$ and $10.1 \pm 7.7 \mathrm{~mm}$ day $^{-1}$, respectively). Melt rates were significantly different at the $5 \%$ significance level when compared among pre- and post-wildfire periods and the burned and unburned site. The burned and unburned sites had reductions in average melt rates of -2 and $-1.4 \mathrm{~mm} \mathrm{day}^{-1}$, respectively, between the post and pre-wildfire periods (Table 3 ).

\section{Discussion}

\section{a. BC depositional variability}

We attribute the decrease in $\mathrm{BC}$ concentration in surface samples with increased burn age to the reduction in charred material remaining on the snags as they decay and fall. Field observations show an evident change in the visible snag conditions between the younger and older burn sites, especially in the dominant Abies species (grand and subalpine fir) that shed their outer bark in large segments (Gleason and Nolin 2016). The differences in snag conditions coincide with the amount of material shed onto the surrounding snowpack (Fig. 3). Postmortem snag decay rates reported by Everett et al. (1999) and Dunn and Bailey (2012) demonstrate that thin-barked conifers can decay for up to 80 years following a wildfire, though $50 \%$ of trees in a given burn area will have fallen within 25 years. Substantial snag fall was observed in the Tripod Complex, while virtually all

TABLE 2. Modeled all-sky broadband albedo $(0.305-5.00 \mu \mathrm{m})$ and maximum/daily mean radiative forcing with increasing BC concentrations (corresponding to Fig. 4), effective grain size (300 and $700 \mu \mathrm{m})$, and all-sky irradiance for 15 Apr and 15 May.

\begin{tabular}{|c|c|c|c|c|c|c|}
\hline \multirow[b]{2}{*}{$\mathrm{BC}\left(\mathrm{ng} \mathrm{g}^{-1}\right)$} & \multicolumn{3}{|c|}{15 April } & \multicolumn{3}{|c|}{15 May } \\
\hline & Albedo & Max daily $\mathrm{RF}\left(\mathrm{W} \mathrm{m}^{-2}\right)$ & Mean daily $\mathrm{RF}\left(\mathrm{W} \mathrm{m}^{-2}\right)$ & Albedo & Max daily $\mathrm{RF}\left(\mathrm{W} \mathrm{m}^{-2}\right)$ & Mean daily $\mathrm{RF}\left(\mathrm{W} \mathrm{m}^{-2}\right)$ \\
\hline \multicolumn{7}{|c|}{$300 \mu \mathrm{m}$} \\
\hline 0 & 0.81 & & & 0.78 & & \\
\hline 10 & 0.80 & 4.3 & 2.4 & 0.77 & 4.6 & 2.7 \\
\hline 50 & 0.79 & 16.0 & 8.8 & 0.76 & 16.9 & 9.9 \\
\hline 100 & 0.78 & 26.3 & 14.5 & 0.75 & 27.7 & 16.2 \\
\hline 500 & 0.72 & 72.5 & 40.3 & 0.69 & 76.7 & 44.9 \\
\hline 1000 & 0.67 & 106.6 & 59.4 & 0.65 & 113.0 & 66.2 \\
\hline 5000 & 0.51 & 230.7 & 129.2 & 0.50 & 245.7 & 144.1 \\
\hline \multicolumn{7}{|c|}{$700 \mu \mathrm{m}$} \\
\hline 0 & 0.76 & & & 0.73 & & \\
\hline 10 & 0.75 & 6.1 & 3.5 & 0.72 & 6.4 & 3.9 \\
\hline 50 & 0.73 & 23.0 & 13.0 & 0.70 & 24.2 & 14.4 \\
\hline 100 & 0.71 & 37.6 & 21.2 & 0.68 & 39.6 & 23.7 \\
\hline 500 & 0.63 & 101.5 & 57.4 & 0.60 & 107.2 & 63.9 \\
\hline 1000 & 0.57 & 146.3 & 82.8 & 0.55 & 154.9 & 92.3 \\
\hline 5000 & 0.38 & 292.6 & 165.9 & 0.37 & 311.2 & 184.9 \\
\hline
\end{tabular}



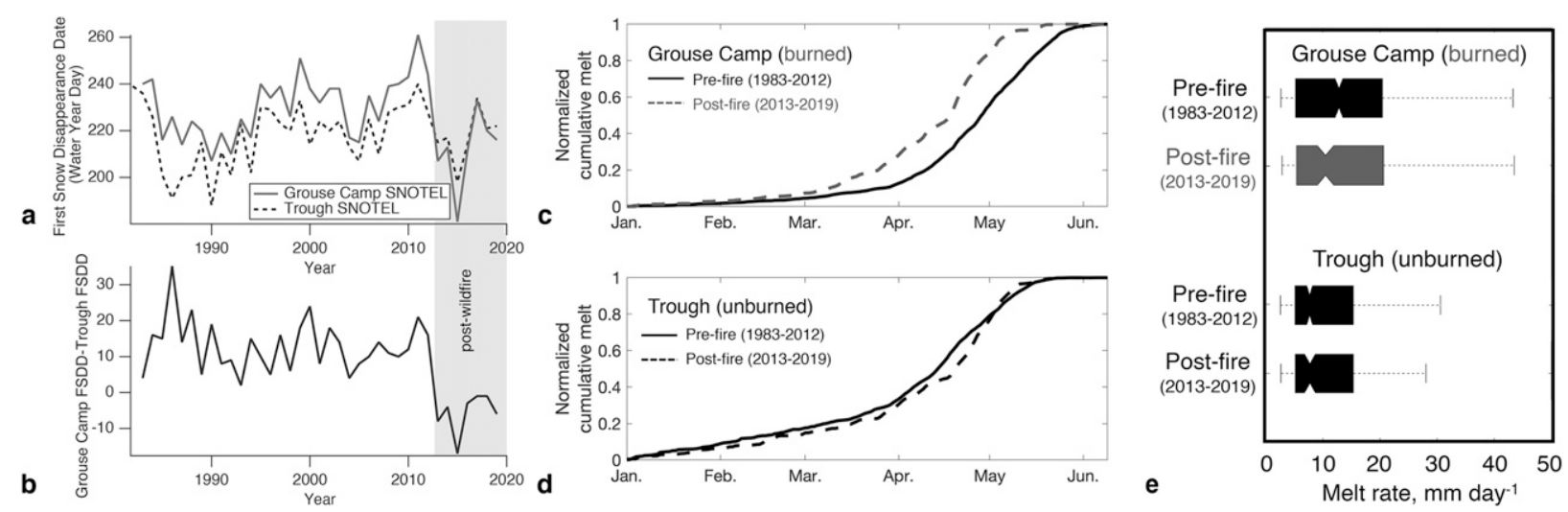

FIG. 5. Variations in FSDD, cumulative daily melt, and daily melt rates for Trough and Grouse Camp SNOTEL sites. (a) Snow FSDD for the Trough and Grouse Camp SNOTEL stations. (b) Grouse Camp FSDD minus Trough FSDD. The shaded gray box in (a) and (b) highlights the post-wildfire period. (c) Cumulative daily melt from January to snow FSDD normalized by total melt for pre-wildfire and post-wildfire years. (d) As in (c), but for the unburned Trough SNOTEL sites. (e) Boxplots showing the measured melt rates pre- and postwildfire after 1 Jan at (upper boxes) Grouse Camp (burned) pre- and post-wildfire compared to that measured at the (lower boxes) control (unburned) Trough site.

trees in the younger burn areas remained standing. BC deposition likely continues beyond the maximum age sampled, but with decreased rates of deposition. We acknowledge that comparisons of BC concentrations at sites of varying burn age did not control for differences in forest composition. Additional characterization of the forest composition and density would help to more accurately define the relationship between $\mathrm{BC}$ deposition and burn age.

The increase in $\mathrm{BC}$ concentration with burn severity suggests that higher severity burns potentially have greater impact on snow albedo than lower severity burns. Changes to the natural forest ecology in the eastern Cascades through resource management and fire suppression have led to denser forests and an increased assemblage of fire-susceptible conifer species in low- to midelevation forests (Arno 1980; Smith and Fischer
1997; Wright and Agee 2004). These changes, coupled with climate-induced tree stress and mortality, can lead to an increased fuel load, which may result in higher severity fires (Everett et al. 1999; Westerling et al. 2006; Allen et al. 2010). Burn severity is defined as the degree of alteration or disruption, which in turn is measured through effects on the dominant vegetation (Smith and Fischer 1997). While it is known that higher severity fires reduce the canopy to a greater degree, the results of this study suggest that BC production and deposition on the snowpack increases with burn severity. The wide range of $\mathrm{BC}$ concentrations observed in areas of differing burn severity is attributed to the heterogeneous deposition of $\mathrm{BC}$ as well as the variable pre-wildfire forest conditions such as tree density, species assemblage, and tree health that would require further study. This

TABLE 3. Grouse Camp SNOTEL observed peak SWE, water year (day $1=1$ Oct) day of peak SWE, FSDD, normalized melt frequency, and average daily melt rates $\left(\mathrm{mm} \mathrm{day}^{-1}\right) \geq 2.54 \mathrm{~mm}$ occurring after $1 \mathrm{Jan}$ for pre- and post-wildfire water years.

\begin{tabular}{lccccc}
\hline \multicolumn{1}{c}{ Time period } & $\begin{array}{c}\text { Peak } \\
\text { SWE (mm) }\end{array}$ & $\begin{array}{c}\text { Water yearday of } \\
\text { peak SWE }\end{array}$ & $\begin{array}{c}\text { Water year } \\
\text { snowpack FSDD }\end{array}$ & $\begin{array}{c}\text { Normalized melt } \\
\text { frequency }\end{array}$ & $\begin{array}{c}\text { Average melt rate } \geq 2.54 \text { mm } \\
\text { after 1 Jan (mm day }\end{array}$ \\
\hline Pre-wildfire (1983-2012) & 535 & \multicolumn{2}{c}{ Grouse Camp (burned site) } \\
Post-wildfire (2013-19) & 452 & 181 & 230 & 0.30 & 15.35 \\
Difference (post-wildfire & -83 & -11 & 212 & 0.32 & 13.75 \\
$\quad$ minus pre-wildfire) & & & Trough (unburned site) & & -2 \\
Pre-wildfire (1983-2012) & 293 & 168 & 217 & 0.28 & 11.5 \\
Post-wildfire (2013-19) & 316 & 176 & 218 & 0.33 & 10.1 \\
Difference (post-wildfire & +23 & +8 & +1 & +0.05 & -1.4 \\
minus pre-wildfire) & & & & \\
\hline
\end{tabular}


highlights the importance of an extensive sampling campaign needed to quantify spatial variability.

\section{b. Impact of BC on snow albedo and radiative forcing}

The snow albedo and radiative forcing model results (section 3c, Table 2, Fig. 4) demonstrate that the impact from $\mathrm{BC}$ on both albedo and radiative forcing is not only dependent on $\mathrm{BC}$ concentrations, but also on the grain size, with a higher RF efficacy as grains get larger over time, and irradiance, with higher RF as solar irradiance increases through the spring. These are all important factors that contribute to the melt efficacy of $\mathrm{BC}$. The additional energy from $\mathrm{BC}$ at the snow surface accelerates the rate of snow grain growth, lowering snow albedo over the full range of snow reflectance and providing more energy for melt. As melt progresses, previously deposited $\mathrm{BC}$ concentrates at the snow surface, a process known as melt amplification (Doherty et al. 2014). This feedback loop not only compounds albedo decay but also coincides with increasing sun angles and longer days in the spring.

Our simple treatment of BC in snow likely underestimates the total radiative impact for several reasons. It only accounts for the direct impact of snow darkening, and not the indirect impact of accelerated snow grain growth. It also only accounts for BC and not other LAP like dust or brown carbon, which are also present in the snow. Furthermore, we do not distinguish among BC source material, so the optical properties remain constant across scenarios, which may not be the case for BC particles adhering to larger burned woody debris. Last, this approach treats irradiance for clear or cloudy sky conditions, but does not account for forest shading or changes in the canopy, important controls on surface solar irradiance.

\section{c. Post-wildfire snowmelt dynamics}

\section{1) EARLIER SNOW DISAPPEARANCE AND CHANGES IN MELT FREQUENCY AND RATE}

Our analysis of post-wildfire snowmelt dynamics was facilitated by the relative comparison of pre versus postwildfire metrics at the proximal burned Grouse Camp and unburned Trough SNOTEL sites, which allowed us to control for interannual variability between the sites. In the 30-yr pre-wildfire record, Grouse Camp never became snow-free before Trough. Post-wildfire, snow disappeared $19 \pm 9$ days earlier at the burned Grouse Camp than the unburned Trough site. This is a larger effect than reported by Gleason et al. (2019) based on satellite imagery of 850 fires in the western United States, which showed snow disappeared 5 days earlier on average, but within the 23 days earlier snowmelt reported by Gleason et al. (2013) based on measurements of snowpack surface debris and SWE in burned and unburned forests in the Oregon Cascades.

Using the controlled SNOTEL site assessment, we show that the shift to earlier post-wildfire snow disappearance was coincident with a shift to earlier snowmelt at the burned Grouse Camp site but not the unburned Trough site (i.e., compare Fig. 5c to 5d). At Grouse Camp, 2.4 times more melt occurred before 1 April and nearly half as much snowmelt persisted into May, compared to pre-wildfire conditions. However, the earlier, post-wildfire snowmelt at the burned site did not occur more frequently or at higher rates, on average, compared to the pre-wildfire period. In fact, snowmelt rates were on average slightly lower postwildfire at both the control and burned sites (Table 3 ). A possible explanation is that snowmelt began 2030 days earlier post-wildfire due to higher concentrations of LAP on the snow surface. Earlier melt onset and snow disappearance post-wildfire shifted the snowmelt period to a time of lower energy available to melt the snow (Musselman et al. 2017). Lower surface albedo values due to higher LAP concentrations may have offset this potential reduction in incoming solar radiation.

\section{2) Modeled CONTRibution of BC TO MELT RATES}

We used the SNICAR radiative transfer model to better understand how radiative forcing by BC would have accelerated melt before and after the fire (Table 4). Simulations were conducted for two distinct time periods corresponding to snowmelt periods defined as the dates over which $25 \%-75 \%$ of the cumulative melt (measured at Grouse Camp) occurred. Prewildfire (1983-2012), this time period is 14 April12 May, while post-wildfire it is $\sim 18$ days earlier from 27 March to 26 April. We assume that snow has a background $\mathrm{BC}$ concentration of $10 \mathrm{ngg}^{-1}$ (Fig. 3; Delaney et al. 2015), which itself would have contributed $0.4 \pm 0.1 \mathrm{~mm} \mathrm{day}^{-1}$ (with the \pm 0.1 - $\mathrm{mm}$ range due to range in modeled grain size) of melt during spring pre-wildfire. We also calculate the additional melt due to BC post-wildfire, and assume that the hypothetical site is in the open and unaffected preand post-wildfire by forest shading. For the highest $\mathrm{BC}$ concentration sampled $\left(5000 \mathrm{ng} \mathrm{g}^{-1}\right)$ at 0.7 years post-wildfire in a high severity burn area, the modeled post-wildfire daily melt contribution is an extreme $19.1 \pm 2.4 \mathrm{~mm} \mathrm{day}^{-1}$. For 1000,500 , and the median $300 \mathrm{ng} \mathrm{g}^{-1} \mathrm{BC}$ concentrations, the modeled daily melt contribution is $9.20 \pm 1.51,6.32 \pm 1.11$, and $3.71 \pm 0.57 \mathrm{~mm} \mathrm{day}^{-1}$, respectively (Table 4). 
TABLE 4. Modeled snowmelt rates due to radiative forcing, for the range of sampled BC concentrations, with ( \pm ) due to the range of modeled grain sizes. Note that we assume that the pre-wildfire BC concentration was $10 \mathrm{ng} \mathrm{g}^{-1}$ (indicated with *), but show accelerated melt for this time frame for comparison purposes. Additional melt is calculated for higher $\mathrm{BC}$ concentration in the post-wildfire period, relative to the background $\mathrm{BC}$ concentration in the pre-wildfire period $\left(0.4 \pm 0.1 \mathrm{~mm} \mathrm{day}^{-1}\right)$.

\begin{tabular}{cccc}
\hline $\begin{array}{c}\text { Black carbon } \\
\text { concentration }\left(\mathrm{ng} \mathrm{g}^{-1}\right)\end{array}$ & $\begin{array}{c}\text { Pre-wildfire (14 Apr-12 May) RF } \\
\left.\text { melt equivalent (mm day }{ }^{-1}\right)\end{array}$ & $\begin{array}{c}\text { Post-wildfire (27 Mar-26 Apr) } \\
\left.\text { RF melt equivalent (mm day }^{-1}\right)\end{array}$ & $\begin{array}{c}\text { Additional post-wildfire melt due } \\
\left.\text { to BC RF (mm day }^{-1}\right)\end{array}$ \\
\hline 10 & $* 0.4 \pm 0.1$ & $0.4 \pm 0.1$ & - \\
300 & $4.2 \pm 0.8$ & $3.7 \pm 0.6$ & 3.3 \\
500 & $7.0 \pm 1.2$ & $6.3 \pm 1.1$ & 5.9 \\
1000 & $10.3 \pm 1.7$ & $9.2 \pm 1.5$ & 8.8 \\
5000 & $21.3 \pm 2.6$ & $19.1 \pm 2.4$ & 18.7 \\
\hline
\end{tabular}

The additional simulated post-wildfire melt, relative to the pre-wildfire period, ranges from $\sim 3$ to $19 \mathrm{~mm}$ day $^{-1}$ for the median to maximum sampled $\mathrm{BC}$ concentrations. These values are intended to show 1) the potential magnitude of impact due to sampled $\mathrm{BC}$ concentrations, and 2) that the BC RF impact is slightly lower when snowmelt shifts to earlier in the season. The pre- and post-wildfire snowmelt observations imply that wildfire may not ubiquitously accelerate runoff production across the fire-prone and snow-dominated western United States. However, we caution that a direct comparison of modeled to observed pre- and postwildfire melt rates (Table 3 ) is complicated by other energy balance factors that are implicitly included in the observations but not in the radiative transfer model, particularly the removal of forest canopy.

\section{d. Additional considerations and future research}

Forest canopy removal is likely to have longer-term impacts on post-wildfire snowmelt dynamics than LAP deposition. This study shows that post wildfire BC deposition in high severity wildfire areas persists for at least $\sim 10$ years, and Gleason et al. (2019) documents a similar effect lasting 15 years. In contrast, the effects of canopy removal from a stand-replacing fire can last several decades as new growth reaches full maturity (Smith and Fischer 1997). Beneath a continuous forest canopy, melt energy is primarily in the form of net longwave radiation (Lundquist et al. 2013). Decreasing forest cover reduces downward longwave irradiance contributed by the canopy and increases the shortwave radiation reaching the snow surface. At a certain forest cover threshold-determined by site conditions including snow albedo, seasonality, and climate-net solar radiation becomes the dominant source of melt energy (Lawler and Link 2011). Canopy removal by wildfire abruptly causes this radiative switch, decreasing the longwave contributed by surrounding trees (Musselman and Pomeroy 2017) and increasing shortwave radiation at the snow surface. Postwildfire deposition of LAP further enhances the net shortwave radiation by decreasing the snow surface albedo. Additionally, canopy removal by wildfire would increase surface wind speed and turbulent energy transfer to the snow surface.

Further research would be needed to reconcile the spatial variability in BC/LAP deposition and heterogeneity in both burn severity and canopy removal with radiative forcing and accelerated snowmelt. Small forest gaps, where SNOTEL sites are commonly situated (Fig. 2), have complex radiative energy balances compared to open or continuously forested sites and may respond to canopy removal differently than a continuously forested site (Musselman et al. 2012, 2015). Thus, more work across a continuum of forest density and structure, as well as incorporation of pre- and postfire forest shading into the radiative transfer model is needed to understand the impact of wildfire on snowmelt rates and runoff production as it relates to flood risk and seasonal streamflow.

This study also looks at the effects of wildfire age and burn severity on BC deposition separately. There is still uncertainty about the interactions of these two parameters on BC deposition, such as the controls of burn severity on $\mathrm{BC}$ deposition over time. There is also the opportunity for further work on the effects of wildfire age and burn severity on BC spatial distribution and the production, occurrence, and transport of other LAP.

\section{Conclusions}

Wildfires in the eastern Cascade Range contribute to snowmelt through post-wildfire deposition of $\mathrm{BC}$ and other LAP that increase absorption of solar radiation, and removal of the forest canopy, which increases incoming solar radiation to the surface. Our research shows that burned trees in post-wildfire forests may provide a source of $\mathrm{BC}$ and other LAP for years following a wildfire, with $\mathrm{BC}$ concentrations decreasing by an order of magnitude over a decade. Furthermore, $\mathrm{BC}$ concentrations are two orders of magnitude higher in high burn severity forests relative to low burn severity forests. 
A comparison of the burned Grouse Camp and unburned Trough SNOTEL sites indicates that complete snowmelt occurred on average $19 \pm 9$ days earlier in the post-wildfire period (2013-19) at Grouse Camp relative to the pre-wildfire period (1983-2012). Melt occurred earlier post-wildfire at the burned site, with $84 \%$ of snowmelt occurring before 1 May in the post-wildfire forest compared to $56 \%$ in the pre-wildfire forest.

Understanding the connection between wildfires and snowmelt has implications for water resources and understanding climate change feedbacks. In Washington State, warming temperatures have led to an observed decrease in the extent and duration of the seasonal snowpack (Mote et al. 2018). There has also been an observed increase in wildfire frequency, magnitude, severity, and duration in the western United States since the 1980s (Westerling et al. 2006). Current climate change models indicate that the snowpack in the Cascades will decrease (Elsner et al. 2010; Miles et al. 2010), while the area burned by wildfires and the duration of the fire season are expected to increase (Littell et al. 2010; Flannigan et al. 2013). Predicting the impact of these changes requires a better understanding of the connection between wildfire activity and snowmelt. The results of this study show the wildfire impacts of LAP deposition can persist for at least a decade post-wildfire, and may alter snow dynamics and runoff patterns in the fire-prone and snow-dominated western United States. The advanced snowmelt timing of $19 \pm 9$ days is in agreement with similar studies such as Gleason et al. (2013), and the effect of LAP deposition lasting beyond 10 years is comparable to Gleason et al. (2019). Studies such as this provides important information for improved water resource and land management and may inform strategies for meeting ecological and societal water demands. Our research may also help to improve our understanding of snowmelt processes, which currently contain large uncertainties in the energy balance components and often do not account for the role of BC and other LAP (Skiles et al. 2018).

Acknowledgments. This research was supported by a grant from the United States Geological Survey and State of Washington Water Research Center (2015WA394B), a Geological Society of America Graduate Research Grant, and the Central Washington University School of Graduate Studies summer fellowship. We thank Dave Peterson (USFS), John Rohrer (USFS), Richy Harrod (USFS) and Brian Mize (Nature Conservancy) for assistance selecting and accessing study sites, snag identification, and information on wildfire ecology. Scott Pattee (USDA) provided photographs of the pre- and post-wildfire SNOTEL sites.
Tyler Starks and Ben Stone assisted with sample collection, preparation, and analysis. We thank the three anonymous reviewers and the editor for their constructive feedback.

\section{REFERENCES}

Allen, C. D., A. K. Macalady, H. Chenchouni, D. Bachelet, N. McDowell, M. Vennetier, and P. Gonzalez, 2010: A global overview of drought and heat-induced tree mortality reveals emerging climate change risks for forests. For. Ecol. Manage., 259, 660-684, https://doi.org/10.1016/j.foreco.2009.09.001.

Andreae, M. O., and A. Gelencsér, 2006: Black carbon or brown carbon? The nature of light-absorbing carbonaceous aerosols. Atmos. Chem. Phys., 6, 3131-3148, https://doi.org/10.5194/ acp-6-3131-2006.

Arno, S. F., 1980: Forest fire history of the northern Rockies. J. For., 39, 726-728.

Barnett, T. P., J. C. Adam, and D. P. Lettenmaier, 2005: Potential impacts of a warming climate on water availability in snowdominated regions. Nature, 438, 303-309, https://doi.org/ 10.1038/nature04141.

Burles, K., and S. Boon, 2011: Snowmelt energy balance in a burned forest plot, Crowsnest Pass, Alberta, Canada. Hydrol. Processes, 25, 3012-3029, https://doi.org/10.1002/hyp.8067.

Delaney, I., S. Kaspari, and M. Jenkins, 2015: Black carbon concentrations in snow at Tronsen Meadow in Central Washington from 2012 to 2013: Temporal and spatial variations and the role of local forest fire activity. J. Geophys. Res. Atmos., 120, 9160-9172, https://doi.org/10.1002/2015jd023762.

Doherty, S. J., C. M. Bitz, and M. G. Flanner, 2014: Biases in modeled surface snow BC mixing ratios in prescribed-aerosol climate model runs. Atmos. Chem. Phys., 14, 11 697-11 709 , https://doi.org/10.5194/acp-14-11697-2014.

Dunn, C. J., and J. D. Bailey, 2012: Temporal dynamics and decay of coarse wood in early seral habitats of dry-mixed conifer forests in Oregon's Eastern Cascades. For. Ecol. Manage., 276, 71-81, https://doi.org/10.1016/j.foreco.2012.03.013.

Eidenshink, J., B. Schwind, K. Brewer, Z. Zhu, B. Quayle, and S. Howard, 2007: A project for monitoring trends in burn severity. Fire Ecol., 3, 3-21, https://doi.org/10.4996/fireecology.0301003.

Elsner, M. M., and Coauthors, 2010: Implications of 21st century climate change for the hydrology of Washington State. Climatic Change, 102, 225-260, https://doi.org/10.1007/s10584010-9855-0.

Everett, R., J. Lehmkuhl, R. Schellhaas, P. Ohlson, D. Keenum, H. Riesterer, and D. Spurbeck, 1999: Snag dynamics in a chronosequence of 26 wildfires on the east slope of the Cascade Range in Washington State, USA. Int. J. Wildland Fire, 9, 223-234, https://doi.org/10.1071/WF00011.

Flanner, M. G., C. S. Zender, J. T. Randerson, and P. J. Rasch, 2007: Present-day climate forcing and response from black carbon in snow. J. Geophys. Res., 112, D11202, https://doi.org/ 10.1029/2006JD008003.

— _ - _ P. G. Hess, N. M. Mahowald, T. H. Painter, V. Ramanathan, and P. J. Rasch, 2009: Springtime warming and reduced snow cover from carbonaceous particles. Atmos. Chem. Phys., 9, 2481-2497, https://doi.org/10.5194/acp-9-2481-2009.

Flannigan, M., A. S. Cantin, W. J. De Groot, M. Wotton, A. Newbery, and L. M. Gowman, 2013: Global wildland fire season severity in the 21st century. For. Ecol. Manage., 294, 54-61, https://doi.org/10.1016/j.foreco.2012.10.022. 
Gao, R. S., and Coauthors, 2007: A novel method for estimating light-scattering properties of soot aerosols using a modified single-particle soot photometer. Aerosol Sci. Technol., 41, 125-135, https://doi.org/10.1080/02786820601118398.

Gleason, K. E., and A. W. Nolin, 2016: Charred forests accelerate snow albedo decay: Parameterizing the post-fire radiative forcing on snow for three years following fire. Hydrol. Processes, 30, 3855-3870, https://doi.org/10.1002/hyp.10897.

_, _ and T. R. Roth, 2013: Charred forests increase snowmelt: Effects of burned woody debris and incoming solar radiation on snow ablation. Geophys. Res. Lett., 40, 4654-4661, https://doi.org/10.1002/grl.50896.

- J. R. McConnell, M. M. Arienzo, N. Chellman, and W. M. Calvin, 2019: Four-fold increase in solar forcing on snow in western U.S. burned forests since 1999. Nat. Commun., 10, 2026, https://doi.org/10.1038/s41467-019-09935-y.

Hall, A., 2004: The role of surface albedo feedback in climate. J. Climate, 17, 1550-1568, https://doi.org/10.1175/15200442(2004)017<1550:TROSAF > 2.0.CO;2.

Hansen, J., and L. Nazarenko, 2004: Soot climate forcing via snow and ice albedos. Proc. Natl. Acad. Sci. USA, 101, 423-428, https://doi.org/10.1073/pnas.2237157100.

Harpold, A. A., and Coauthors, 2014: Changes in snow accumulation and ablation following the Las Conchas Forest Fire, New Mexico, USA. Ecohydrology, 7, 440-452, https://doi.org/ 10.1002/eco.1363.

Kaspari, S. D., M. Schwikowski, M. Gysel, M. G. Flanner, S. Kang, S. Hou, and P. A. Mayewski, 2011: Recent increase in black carbon concentrations from a Mt. Everest ice core spanning 1860-2000 AD. Geophys. Res. Lett., 38, 5-10, https://doi.org/ 10.1029/2010GL046096.

— S. M. Skiles, I. Delaney, D. Dixon, and T. H. Painter, 2015: Accelerated glacier melt on Snow Dome, Mount Olympus, Washington, USA, due to deposition of black carbon and mineral dust from wildfire. J. Geophys. Res. Atmos., 120, 2793 2807, https://doi.org/10.1002/2014jd022676.

Lawler, R. R., and T. E. Link, 2011: Quantification of incoming allwave radiation in discontinuous forest canopies with application to snowmelt prediction. Hydrol. Processes, 25, 3322-3331, https://doi.org/10.1002/hyp.8150.

Li, D., M. L. Wrzesien, M. Durand, J. Adam, and D. P. Lettenmaier, 2017: How much runoff originates as snow in the western United States, and how will that change in the future? Geophys. Res. Lett., 44, 6163-6172, https://doi.org/10.1002/ 2017 GL073551.

Li, F., S. Levis, and D. S. Ward, 2013: Quantifying the role of fire in the Earth system-Part 1: Improved global fire modeling in the Community Earth System Model (CESM1). Biogeosciences, 10, 2293-2314, https://doi.org/10.5194/bg-10-2293-2013.

Littell, J. S., E. E. Oneil, D. McKenzie, J. A. Hicke, J. A. Lutz, R. A. Norheim, and M. M. Elsner, 2010: Forest ecosystems, disturbance, and climatic change in Washington State, USA. Climatic Change, 102, 129-158, https://doi.org/10.1007/s10584-010-9858-x.

Lundquist, J. D., S. E. Dickerson-Lange, J. A. Lutz, and N. C. Cristea, 2013: Lower forest density enhances snow retention in regions with warmer winters: A global framework developed from plot-scale observations and modeling. Water Resour. Res., 49, 6356-6370, https://doi.org/10.1002/wrcr.20504.

Menking, J. A., 2013: Black carbon measurements of snow and ice using a Single Particle Soot Photometer: Method development and an AD 1852-1999 record of atmospheric black carbon from a Mount Logan ice core. Central Washington University, 200 pp., http://www.geology.cwu.edu/grad/menking/thesis/.
Miles, E. L., M. M. Elsner, J. S. Littell, L. W. Binder, and D. P. Lettenmaier, 2010: Assessing regional impacts and adaptation strategies for climate change: The Washington Climate Change Impacts Assessment. Climatic Change, 102, 9-27, https://doi.org/10.1007/s10584-010-9853-2.

Mori, T., N. Moteki, S. Ohata, M. Koike, K. Goto-Azuma, Y. Miyazaki, and Y. Kondo, 2016: Improved technique for measuring the size distribution of black carbon particles in liquid water. Aerosol Sci. Technol., 50, 242-254, https:// doi.org/10.1080/02786826.2016.1147644

Mote, P. W., 2006: Climate-driven variability and trends in mountain snowpack in western North America. J. Climate, 19, 6209-6220, https://doi.org/10.1175/JCLI3971.1.

— S. Li, D. P. Lettenmaier, M. Xiao, and R. Engel, 2018: Dramatic declines in snowpack in the western US. npj Climate Atmos. Sci., 1, 2, https://doi.org/10.1038/s41612-018-0012-1.

Musselman, K. N., and J. W. Pomeroy, 2017: Estimation of needleleaf canopy and trunk temperatures and longwave contribution to melting snow. J. Hydrometeor., 18, 555-572, https://doi.org/ 10.1175/JHM-D-16-0111.1.

— , N. P. Molotch, S. A. Margulis, P. B. Kirchner, and R. C. Bales, 2012: Influence of canopy structure and direct beam solar irradiance on snowmelt rates in a mixed conifer forest. Agric. For. Meteor., 161, 46-56, https://doi.org/10.1016/ j.agrformet.2012.03.011.

— J. W. Pomeroy, and T. E. Link, 2015: Variability in shortwave irradiance caused by forest gaps: Measurements, modelling, and implications for snow energetics. Agric. For. Meteor., 207, 69-82, https://doi.org/10.1016/j.agrformet.2015.03.014.

— M. P. Clark, C. Liu, K. Ikeda, and R. Rasmussen, 2017: Slower snowmelt in a warmer world. Nat. Climate Change, $\mathbf{7}$, 214-219, https://doi.org/10.1038/nclimate3225.

Nolin, A. W., and C. Daly, 2006: Mapping "at risk" snow in the Pacific Northwest. J. Hydrometeor., 7, 1164-1171, https:// doi.org/10.1175/JHM543.1.

Painter, T. H., S. M. Skiles, J. S. Deems, A. C. Bryant, and C. C. Landry, 2012: Dust radiative forcing in snow of the Upper Colorado River Basin: 1. A 6 year record of energy balance, radiation, and dust concentrations. Water Resour. Res., 48, W07521, https://doi.org/10.1029/2012WR011985.

Ricchiazzi, P., S. Yang, C. Gautleir, and D. Sowle, 1998: SBDART: A research and teaching software tool for plane-parallel radiative transfer in the Earth's atmosphere. Bull. Amer. Meteor. Soc., 79, 2101-2114, https://doi.org/10.1175/15200477(1998)079<2101:SARATS > 2.0.CO;2.

Schwarz, J. P., S. J. Doherty, F. Li, S. T. Ruggiero, C. E. Tanner, A. E. Perring, R. S. Gao, and D. W. Fahey, 2012: Assessing Single Particle Soot Photometer and Integrating Sphere/ Integrating Sandwich Spectrophotometer measurement techniques for quantifying black carbon concentration in snow. Atmos. Meas. Tech., 5, 2581-2592, https://doi.org/10.5194/amt5-2581-2012.

Skiles, S., and T. Painter, 2017: Daily evolution in dust and black carbon content, snow grain size, and snow albedo during snowmelt, Rocky Mountains, Colorado. J. Glaciol., 63, 118132, https://doi.org/10.1017/jog.2016.125.

, - J. S. Deems, A. C. Bryant, and C. C. Landry, 2012: Dust radiative forcing in snow of the Upper Colorado River Basin: 2. Interannual variability in radiative forcing and snowmelt rates. Water Resour. Res., 48, 1-11, https://doi.org/ 10.1029/2012WR011986

, M. G. Flanner, J. Cook, M. Dumont, and T. H. Painter, 2018: Radiative forcing by light absorbing particles in snow. Nat. 
Climate Change, 8, 964-971, https://doi.org/10.1038/s41558018-0296-5.

Smith, J. K., and W. C. Fischer, 1997: Fire ecology of the forest habitat types of northern Idaho. USDA Forest Service General Tech. Rep. INT-GTR-363, 142 pp., https:// www.fs.fed.us/rm/pubs_int/int_gtr363.pdf.

Torres, A., T. C. Bond, C. M. B. Lehmann, R. Subramanian, and O. L. Hadley, 2014: Measuring organic carbon and black carbon in rainwater: Evaluation of methods. Aerosol Sci. Technol., 48, 239-250, https://doi.org/10.1080/02786826.2013.868596.

Trujillo, E., and N. P. Molotch, 2014: Snowpack regimes of the western United States. Water Resour. Res., 50, 5611-5623, https://doi.org/10.1002/2013WR014753.

Vano, J. A., M. J. Scott, N. Voisin, C. O. Stoeckle, A. F. Hamlet, K. E. B. Mickelson, M. M. Elsner, and D. P. Lettenmaier, 2010: Climate change impacts on water management and irrigated agriculture in the Yakima River Basin, Washington, USA. Climatic Change, 102, 287-317, https://doi.org/10.1007/ s10584-010-9856-z.
Warren, S. G., and W. J. Wiscombe, 1980: A model for the spectral albedo of snow. I: Pure snow. J. Atmos. Sci., 37, 2712-2733, https:// doi.org/10.1175/1520-0469(1980)037<2712:AMFTSA>2.0.CO;2.

Wendl, I. A., J. A. Menking, R. Färber, M. Gysel, S. D. Kaspari, M. J. G. Laborde, and M. Schwikowski, 2014: Optimized method for black carbon analysis in ice and snow using the Single Particle Soot Photometer. Atmos. Meas. Tech., 7, 26672681, https://doi.org/10.5194/amt-7-2667-2014.

Westerling, A. L., H. G. Hidalgo, D. R. Cayan, and T. W. Swetnam, 2006: Warming and earlier spring increase western U.S. forest wildfire activity. Science, 313, 940-943, https://doi.org/10.1126/ science.1128834.

Winkler, R. D., 2011: Changes in snow accumulation and ablation after a fire in south-central British Columbia. Streamline Watershed Management Bulletin, Vol. 14, No. 2, FORREX, Kamloops, BC, Canada, 1-7.

Wright, C. S., and J. K. Agee, 2004: Fire and vegetation history in the eastern Cascade Mountains, Washington. Ecol. Appl., 14, 443-459, https://doi.org/10.1890/02-5349. 